\title{
The Obama Administration's Regulatory Review Initiative: A 21 st Century Federal Regulatory Initiative?
}

THOMAS A. HEMPHILL

\begin{abstract}
On January 18, 2011, President Obama signed Executive Order 13563, Improving Regulation and Regulatory Review, which instructs federal regulators to do the following: coordinate their agencies activities to simplify and harmonize rules that may be overlapping, inconsistent, or redundant; determine whether the present and future benefits of a proposed regulation justify its potential costs (including taking into account both quantitative and qualitative factors); increase participation of industry, experts, and the public ("stakeholders") in the formal rule-making process; encourage the use of warnings, default rules, disclosure requirements, and provisions of information to the public as an alternative to traditional "command-and-control" rule-making restricting consumer choice; and mandate a government-wide review of all existing administrative rules to remove outdated regulations. Executive Order 13563 includes a qualitative "values" provision to be considered in the required costbenefit analysis, which can potentially counteract the
\end{abstract}

Thomas A. Hemphill is associate professor of strategy, innovation and public policy at the School of Management, University of Michigan-Flint, Flint, MI. E-mail: thomashe@umflint.edu. 
alleged regulatory reform rationale of President Obama. Furthermore, in Executive Order 13563, President Obama established a deadline of May 18, 2011, for all executive branch agencies to submit their plans to streamline their rulemaking operations and repeal those "overlapping, inconsistent, or redundant" rules. These two issues, along with complementary regulatory review proposals being discussed in the U.S. Congress, are evaluated in this essay.

A

fter two years of demonizing the profiteers of American big business in the media, President Obama recently politically pivoted to began his reelection bid by offering American big business a "peace offering"-what he refers to as a "21st century regulatory system"-that he hopes will revive the nation's economy from its lackluster annual gross domestic product growth rates and consistently high, "European-level" unemployment rate (p. 186). On January 18, 2011, he signed Executive Order 13563, Improving Regulation and Regulatory Review, ${ }^{1}$ which instructs federal regulators to do the following: coordinate their agencies activities to simplify and harmonize rules that may be overlapping, inconsistent, or redundant; determine whether the present and future benefits of a proposed regulation justify its potential costs (including taking into account both quantitative and qualitative factors); increase participation of industry, experts, and the public ("stakeholders") in the formal rule-making process; encourage the use of warnings, default rules, disclosure requirements, and provisions of information to the public as an alternative to traditional "command-and-control" rule-making restricting consumer choice; and mandate a government-wide review of all existing administrative rules to remove outdated regulations.

In his editorial ${ }^{2}$ in the Wall Street Journal, also published on January 18, 2011, President Obama explained the rationale behind Executive Order 13563:

This order requires that federal agencies ensure that regulations protect our safety, health and environment while promoting economic growth. It's a review that will help bring order to regulations that have become a patchwork of over- 
lapping rules, the result of tinkering by administrations and legislators of both parties and the influence of special interests in Washington over decades.

Executive Order 13563 is explicitly designed to affirm and supplement Executive Order 12866 (Regulatory Planning and Review) established in 1993 under the Clinton administration. However, Executive Order 13563 includes a qualitative "values" provision to be considered in the required cost-benefit analysis, which can potentially counteract the alleged regulatory reform rationale of President Obama. Furthermore, in Executive Order 13563, President Obama established a deadline of May 18, 2011 ("within 120 days of the date of this order") for all executive branch agencies to submit their plans to streamline their rulemaking operations and repeal those "overlapping, inconsistent, or redundant" rules (although such agencies have been required to prepare such plans since the establishment of Executive Order 12886). These two issues, along with complementary public policy proposals being discussed in the U.S. Congress ("Regulations from the Executive in Need of Scrutiny [REINS] Act"), will be subsequently addressed in this article.

\section{A TROUBLESOME REGULATORY REVIEW PROVISION}

While Section 1 of Executive Order 13563 specifically reiterates five principles involving consideration of benefits, costs, and burdens from Executive Order 12886, Section 1 also asks federal agencies "to use the best available techniques to quantify [emphasis added] anticipated present and future compliance costs [including those that might result from technological innovation or anticipated behavioral changes] as accurately as possible." What is troubling, however, is the expansion of intangible impacts and potential harms weighted in the mandated cost-benefit analyses of this executive order. Under Section 1, federal agencies may discuss certain values that "are difficult or impossible to quantify." These values, to be considered "where appropriate and permitted by law," include "equity, human dignity, fairness, and distributive impacts."

While in Executive Order 12886, the Clinton administration had discussed the need to consider such values as "distributive 
justice" and "equity" in cost-benefit analyses of federal administrative rules, the Obama administration has further enhanced this "regulatory philosophy" by incorporating the new values of "human dignity" and "fairness," which are, in essence, now an express element to be factored into agency regulatory costbenefit analyses. Some critics believe that these additional intangible values factored into a cost-benefit analysis threaten to "balance" against a particularly heavy assessment of tangible costs. Contrarily, according to regulatory economist Robert $\mathrm{Hahn}^{3}$ :

[U]nder certain plausible conditions, it makes sense for the government to produce less or regulate less than it otherwise would based on a standard benefit-cost model .... For example, including costs associated with income redistribution, raising funds, monitoring and enforcement, or partial compliance makes many regulatory interventions look less attractive. Yet, at least some of these factors are frequently not systematically considered in analyzing the impact of law and regulation, even when they are potentially important.

Developing acceptable working definitions of "human dignity" and "fairness" and applying them to assess the risks that the proposed regulation would abate, as well as the benefits the proposed regulation would generate, could require executive branch technocrats to exercise the wisdom of King Solomon in accurately quantifying these values. Values of "equity, human dignity, fairness, and distributive impacts" are important factors to be debated in the public policy arena-and are, in fact, the grist of such discussion. If indeed these values "are difficult or impossible to quantify," a strong policy argument can be made that the appropriate institution for such intangible values to be discussed and debated is in the U.S. Congress-and not the executive branch-where enabling legislation addressing business regulatory policy is formulated (and qualitative regulatory "boundaries" are defined and articulated) by elected representatives to guide (and "bound") the administrative rule-making processes and executive branch enforcement activities. This approach to regulatory policy development properly restricts the impulse of the executive branch to "legislate by regulation." 


\section{REGULATORY REVIEW DEADLINE RESULTS}

On May 18, 2011, all federal executive branch agencies (although not independent agencies of the federal government) were required to submit plans that retrospectively review their significant administrative rules to the Office of Management and Budget (OMB), Office of Information and Regulatory Affairs (OIRA). On May 26, 2011, the White House announced that 30 federal executive branch agencies had reported on their plans to repeal or revise administrative rules to reduce business compliance costs. ${ }^{4}$ As of June 30, 2011, the OIRA reports on its web site (Reginfo.Gov) that there are presently 134 pending regulatory actions under review, with the Environmental Protection Agency (EPA) (24) and the U.S. Department of Health and Human Services (24) leading this regulatory review effort among executive branch agencies. In a recent presentation ${ }^{5}$ at the American Enterprise Institute, Cass Sunstein, Director of OIRA, proclaimed that the proposed regulatory changes would have a "big impact" on the rail, airline, and medical device industries, as well as health-care facilities and physicians. In fact, Sunstein reported that possible regulatory reforms identified by the U.S. EPA, the U.S. Department of Transportation, and the U.S. Department of Labor combined will generate over $\$ 1$ billion in savings.

Those anticipated federal regulatory cost savings will be welcomed by the American business community, as business regulatory costs in 2008 were recently estimated at \$1.75 trillion annually in a recent U.S. Small Business Administration study conducted by Lafayette College economists Nicole V. Crain and W. Mark Crain of Lafayette College. ${ }^{6}$ Yet, as James Gattuso, senior research fellow in regulatory policy at the Heritage Foundation, argued in his recent testimony before Congress ${ }^{7}$ :

Many of the steps announced last week [by Cass Sunstein, Director of OIRA] are the low-hanging fruit of regulatory excesses which should have been plucked long ago.

Many actions are merely suggestions for a change at a later date. For instance, only two rule changes have been finalized by the EPA.

Moreover, these proposed regulatory rollbacks are far exceeded by new regulations which have been or will be promulgated. ${ }^{8}$ 
Moreover, the Obama initiative was hardly "government wide." It excluded independent agencies such as the Federal Communications Commission, the Securities and Exchange Commission, and the new Consumer Financial Protection Bureau. In so doing, the President excluded from scrutiny many of the largest producers of red tape.

James Gattuso's observation regarding agencies has particular salience. In previous administrations, independent agencies have always followed the lead of the OIRA. In this particular case, however, only the National Labor Relations Board voluntarily submitted a one-page document to the OIRA in response to President Obama's executive order. $^{9}$

According to the Crane and Crane study, regulatory costs in 2008 that impact on U.S. businesses translate to $\$ 8,086$ per employee, with small businesses (fewer than 20 employees) bearing an annual regulatory cost in 2008 of $\$ 10,585$ per employee, or 42 percent greater than medium-sized firms (defined as 20 to 499 employees) and 36 percent higher than regulatory costs confronted by large firms (defined as 500 employees or above). In a recent study conducted by John W. Dawson of Appalachia State University and John J. Seater of North Carolina University, the two economists used the page count of the Code of Federal Regulations as a proxy for the extent of regulation and estimated that the 2008 GDP would be $\$ 11.3$ trillion higher if not for the opportunity costs imposed by federal regulations. ${ }^{10}$ The U.S. Chamber of Commerce identifies the real problem behind this regulatory excess by focusing in on the increasing number of "economically significant regulations," that is, those costing businesses, consumers, and the economy more than $\$ 100$ million. ${ }^{11}$ According to the analysis of the U.S. Chamber of Commerce, during the five-year period of 2006-2010, the number of such economically significant regulations increased by 61 percent, from 139 (2006) to 224 (2010). Over the last two years of the Obama administration (2009-2010), the number of economically significant regulations increased by 24 percent, from 180 in 2008 to a record 224 in 2010.

The benefits associated with regulations, while often a challenge to quantify, are also evaluated by the OMB. The OMB has estimated that the annual benefits of major federal regulations from October 1, 1999 to September 30, 2009, for which agencies 
estimated and monetized both benefits and costs, are in the aggregate between $\$ 128$ billion and $\$ 616$ billion, while the estimated annual costs are in the aggregate between $\$ 43$ billion and $\$ 55$ billion. ${ }^{12}$ Some administrative rules are estimated to produce far higher net benefits than others. Moreover, there is substantial variation across agencies in the total net benefits produced by administrative rules.

\section{REINING IN REGULATION?}

While the Obama administration's efforts at regulatory review are laudable, in most instances, the administrative process to eliminate or better harmonize such rules involves a time frame that could take up to a year to complete, thus having little near-term affect on U.S. job creation and industry competitiveness. ${ }^{13}$ In fiscal year (FY) 2010, based on data provided by the Government Accountability Office, the Heritage Foundation calculated that the annual costs of an unprecedented 43 major regulations would impose \$28 billion annually on American businesses and consumers. ${ }^{14}$ Moreover, the Federal Register, where administrative rules governing interstate business behavior are published, is now at an all-time record of 81,000 pages. ${ }^{15}$ If one wants serious regulatory reform, he or she needs to address this issue where it begins-in the U.S. Congress.

"Regulations," or administrative rules, are the end result of public policy expressed in legal statutes voted upon by the legislature. The executive branch is responsible for developing administrative rules in their agency enforcement of the statute. Thus, the reason for a record 224 economically significant regulations in FY2010 is because the U.S. Congress was actively passing legislation (and the president signing them into law). Better understanding the economic impact, that is, the costs and benefits, of legislation having regulatory effects on business can have a significant influence on what public policy is passed, and the ultimate form of the subsequent administrative rules. The Heritage Foundation has wisely recommended that Congress establish its own Congressional Office of Regulatory Analysis (CORA)-a legislative version of the executive branch's OMB (and OIRA)—so as it may independently review existing and proposed administrative 
rules. ${ }^{16}$ However, CORA could be of great assistance to legislators in providing realistic cost-benefit analysis of proposed statutes before they are voted on to become law, for example, in the case of the Patient Protection and Affordable Care Act of 2010.

In the 112th Congress, both the U.S. House of Representatives (HR. 10) and the U.S. Senate (S. 299) are considering the "Regulations from the Executive in Need of Scrutiny (REINS) Act." The REINS Act requires both houses of Congress to affirmatively approve, and the president to sign, any "economically significant regulation," that is, administrative rule with a projected impact to the U.S. economy exceeding $\$ 100$ million, before it becomes law. The REINS Act, although proposed with good intentions, is not, in its present formulation, a workable solution to the regulatory excess problem. In an interview in Free Enterprise, the U.S. Chamber of Commerce magazine, former OIRA Director (under President George W. Bush) John Graham argued that ${ }^{17}$

Something like the REINS Act is more feasible if you target it to a small number of rules every year where members of Congress would realistically have the time and information available to focus on those rules enough where they could prepare and understand what they are looking at. We already have a problem in Congress in which members vote on a whole bunch of pieces of legislative action when they don't necessarily really know what is in the legislative action. Layer on top of that the idea that members of Congress are going to vote on all these hundreds of regulations, and it's just not realistic.

Moreover, under authority granted to the Congress under the Congressional Review Act of 1996, major administrative rules take effect unless Congress passes and the president signs a joint resolution disapproving them. In the ensuing 15 years, this congressional authority has been successfully exercised only once (an Office of Safety and Health Administration [OSHA] regulation addressing ergonomics in the workplace). Furthermore, this OSHA regulation was disapproved in June 2001, when there were both a Republican president and Republican-controlled Congress, and was the only rule that was disapproved (among tens of thousands implemented) during a six-year period of Republican control of both the executive and legislative branches. For the REINS Act to be effective, and based on experience with the 
Congressional Review Act of 1996, its authority should be limited by specific qualifying criteria, including "super" economically significant regulations-for example, those administrative rules projected to exceed $\$ 250$ million in projected economic impactand/or those regulations that economically impact industries that are critical to U.S. global competitiveness, for example, biotechnology and pharmaceuticals, defense-related, health care, information technology, and nanotechnology. By focusing on a very limited number of such high-impact administrative rules, Congress can realistically allocate its members' time on those administrative rules having maximum economic impact on industries critical to the nation's economic well-being. These proposed regulatory reform recommendations could go a long way to creating that "21st Century Federal Regulatory System" strived for by the Obama administration.

\section{NOTES}

1. Federal Register, "Improving regulation and regulatory review," Executive Order 13563, Presidential Documents, Vol. 76, No. 14, January 18, 2011, 3821-23.

2. B. H. Obama. "Toward a 21 st century regulatory system," Wall Street Journal, January 18, 2011 , A17.

3. R. Hahn. "Designing smarter regulation with improved benefit-cost analysis,” Journal of Benefit-Cost Analysis 1(5): 1-19, 2010.

4. C. Sunstein, "Regulatory look-back: A first look," Presentation at the American Enterprise Institute, May 26, 2011 , Washington, DC.

5. Ibid.

6. N. Crane and W. M. Crain, The Impact of Regulatory Costs on Small Firms (Washington, DC: U.S. Small Business Administration, Office of Advocacy, Summary No. 371, September 2010). The Crain and Crain (2010) study has its critics. For example, small businesses' disproportionate costs for regulation stem primarily from environmental rules, a finding based on data collected in 1992. Winston Harrington, an economist for Resources for the Future (Washington, DC), a reviewer of the 2005 study by W. Mark Crain for the U.S. Small Business Administration, also found serious problems with the methodological approach taken by Crain to measure regulatory costs. See W. Harrington, "Grading estimates of the benefits and costs of federal regulation: A review of 
reviews," Discussion Paper (RFF DP 06-39), Resources for the Future, September 2006, Washington, DC. The Congressional Research Service has also found numerous problems with the Crane and Crane (2010) estimate of the total cost of regulation in the U.S. See C. W. Copeland, "Analysis of an Estimate of the Total Costs of Federal Regulations," CSR Report for Congress, April 6, 2011, Congressional Research Service, Washington, DC. A rejoinder to this Copeland critique is "Response to the CSR Report, Analysis of the Total Costs of Federal Regulation," by N. V. Crain and W. M. Crain, April 28, 2011 @http://policystudies.lafayette. edu/files/2011/03/Response-to-CRS.pdf, accessed April 1, 2012.

7. J. L. Gattuso, "Testimony before the Committee on Energy and Commerce, Subcommittee on Oversight and Investigations, the views of the administration on regulatory reform: An update, United States House of Representatives," Heritage Foundation, June 3, 2011, Washington, DC.

8. J. L. Gattuso, D. Katz, and S. A. Keen, "Red tape rising: Obama's torrent of new regulations," Heritage Foundation Backgrounder, October 26, 2010, No. 2482, Washington, DC.

9. On April 20, 2011, the National Labor Relations Board (NLRB) filed a controversial complaint against the Boeing Company charging the company of setting up a nonunion production line in Charleston, South Carolina to retaliate against unionized workers in Washington State for exercising their right to strike against the aircraft manufacturer. As part of the remedy for the alleged unfair labor practices of Boeing management, the NLRB requires Boeing to have its 787 Dreamliner jet unit operate its second line of aircraft assembly production in the State of Washington and not in South Carolina. See National Labor Relations Board, United States of America Before the National Labor Relations Board, Region 19, Seattle, Washington, "The Boeing Company and International Association of Machinists and Aerospace Workers District Lodge 751, affiliated with International Association of Machinists and Aerospace Workers (Case 19-CA-32431)," April 20, 2011. The Charleston, South Carolina manufacturing facility employees were previously represented by the International Association of Machinists when the plant was owned by Vought, but after its acquisition by Boeing in 2009, the union was decertified by a vote of its employees.

10. J. W. Dawson and J. L. Seater, "Federal regulation and aggregate economic growth," December 2008, http://ideas.repec.org/p/apl/ wpaper/09-02.html, accessed June 30, 2011. The authors of this article note that their study does not address the social benefits of regulation. 
11. W. L. Kovacs, "Testimony before the Committee on Energy and Commerce, Subcommittee on Oversight and Investigations, the views of the administration on regulatory reform: An update, United States House of Representatives," U.S. Chamber of Commerce, June 3, 2011, Washington, DC.

12. Office of Management and Budget (OMB) (Office of Information and Regulatory Affairs), "2010 Report to Congress on the benefits and costs of federal regulations and unfunded mandates on state, local, and tribal entities," 2010, Washington, DC. In its 2010 report, the OMB offers the following important caveat:

It is important to emphasize that the figures here have significant limitations. For example, the aggregate estimates do not capture the non-monetized benefits and costs of rules. Many rules have benefits and costs that cannot be quantified or monetized in light of existing information. In fulfilling their statutory mandates, agencies must often act in face of substantial uncertainty about the likely consequences.

13. Op cit, note 7 .

14. Ibid.

15. C. Stearns, "Stearns finds little progress in administration's regulatory reform agenda,” Press Release, June 3, 2011, Office of Congressman Cliff Stearns (R-FLA), Washington, DC.

16. Op cit, note 7 .

17. U.S. Chamber of Commerce, "Reforming the regulatory process: An insider offers solutions," Free Enterprise Magazine, April 8, 2011, Washington, DC., http://www.uschambermagazine.com/article/ reforming-the-regulatory-process, accessed June 30, 2011. 